\title{
Algae as Functional Foods for the Elderly
}

\author{
Filipa Figueiredo ${ }^{1}$, Telma Encarnação², Maria G. Campos ${ }^{1,2}$ \\ ${ }^{1}$ Faculty of Pharmacy, University of Coimbra, Pólo das Ciências da Saúde, Azinhaga de Santa Comba, Coimbra, Portugal \\ ${ }^{2}$ Chemistry Centre of Coimbra, Faculty of Science and Technology, University of Coimbra, Coimbra, Portugal \\ Email: mgcampos@ff.uc.pt
}

How to cite this paper: Figueiredo, F., Encarnação, T. and Campos, M.G. (2016) Algae as Functional Foods for the Elderly. Food and Nutrition Sciences, 7, 1122-1148. http://dx.doi.org/10.4236/fns.2016.712107

Received: January 18, 2016

Accepted: October 22, 2016

Published: October 25, 2016

Copyright $\odot 2016$ by authors and Scientific Research Publishing Inc. This work is licensed under the Creative Commons Attribution International License (CC BY 4.0).

http://creativecommons.org/licenses/by/4.0/ (c) (i) Open Access

\begin{abstract}
Older people may have more difficulties in acquiring the nutrients they need from diet and they are at greater risk of chronic diseases. Hence, functional foods based on algae, might have a role in improving very important nutrients intake without an increase in calories. This is crucial for middle age people that become less active and will not dispend as much energy as they use to, which will contribute for certain diseases associated with age. Algae produce a great variety of biological active compounds which cannot be found in other organisms. Moreover, they have been reported for their potential medicinal uses. Therefore, they have high potential as a source of functional ingredients. In this review, we will give relevant information about the issue, explain above, pointing out the information related to the compounds that could be responsible for the improvement in quality of life during elderly. It will be also referred that seaweeds can be a source of new compounds for drug discovery.
\end{abstract}

\section{Keywords}

Functional Foods, Algae, Elderly, Antioxidant, Inflammation, Diabetes, Obesity, Neuroprotection

\section{Introduction}

Diet plays a primary role of providing enough nutrients to meet metabolic requirements. However, diet may also modulate various functions in the body, thus playing detrimental or beneficial roles in some diseases [1]. There are scientific papers that correlate diet and some chronic diseases, showing the extraordinary possibility of foods to support, or even improve, our health [2] [3]. Based on this hypothesis, food may not only be used to survive and provide hunger satisfaction, but also to promote the state of well-being and better health and to help to reduce the risk of diseases. This might be 
particularly important given the increasing cost of health care, the steady increase in life expectancy and the desire of older people for improved quality of life [1].

Food that, besides its nutritious effect, has a demonstrated benefit for one or more functions of the human organism, improving the state of health or well-being or reducing the risk of disease, can be considered "functional" [4]. Besides, it has also to have effectiveness at normal consumed doses [5]. The action of functional foods is due to a component or series of ingredients [5], may or may not be nutrients [1], that are not present in the analogous conventional food or are present at lower concentrations. These are called functional ingredients [5].

Older people may have more difficulties in obtaining the nutrients they need from diet, because of age related changes. Moreover, there is an increase in the risk of chronic disease with age, which can mean that older people may need more radical dietary changes to prevent or manage chronic conditions [6]. Hence, functional foods can have a role in improving nutrient intake [7] and in reducing the risk of chronic diseases associated with age [6].

Algae are photosynthetic organisms, with great diversity of forms and sizes, that range from unicellular microscopic organisms (microalgae) to multicellular of great size (macroalgae) [5]. Marine macroalgae, also referred as seaweeds, can be classified into three groups, based on their pigmentation, brown (Phaeophyceae), red (Rhodophyceae) and green (Chlorophyceae) algae [8]. They are, among marine organisms, a rich source of structurally diverse bioactive compounds with various biological activities and their importance as a source of novel bioactive substances is growing [9]-[11].

Some algae live in complex habitats and are submitted to extreme conditions such as changes in salinity, temperature, nutrients, UV-VIS irradiation and others. In order to survive, they must adapt rapidly to the new environmental conditions, producing a great variety of secondary metabolites which cannot be found in other organisms [12]. Many metabolites isolated from marine algae have already been reported for their biological activities and potential health benefits [13]. Current research has revealed that seaweeds have potential medicinal uses against cancer, allergy, diabetes, oxidative stress, inflammation, thrombosis, obesity, lipidemia, hypertensive and other degenerative ailments [14]. Moreover, due to their great taxonomic diversity, the search of new biological active compounds from algae can be seen as an almost unlimited field [5] and marine algae are still identified as an under exploited plant resource [15].

Other important aspects are the fact that algae are easily cultivated, with rapid growing (for many of the species) and the possibility of controlling the production of some bioactive compounds by manipulating the cultivation conditions. Hence, algae and microalgae can be considered natural reactors and a good alternative to chemical synthesis for certain compounds [5].

\section{Main Compounds}

All algae primarily contain proteins, carbohydrates, fats and nucleic acids in varying proportions. Many are cultivated for their nutritional value as they are particularly nu- 
tritious and able to provide many vitamins such as A, B1, B2, B6, niacin and C [16]. Edible seaweeds are also rich in bioactive antioxidants, soluble dietary fibres, minerals, phytochemicals and polyunsaturated fatty acids, with low caloric value. However, nutrient contents are affected by external aspects such as geographic location, environmental conditions and season [14]. Besides their nutritional value as supplements and food source [16] seaweeds have revealed to possess numerous beneficial health effects [17]. They have been shown to have therapeutic properties for health and disease management, such as antioxidant, antitumor, anti-inflammatory, anti-obesity, neuroprotective, among other properties [14]. These activities are due to active compounds including sulphated polysaccharides (SP), phlorotannins, peptides [14] and natural pigments (NP) [13].

Marine algae represent the most important non-animal source of sulphated polysaccharides. These compounds are anionic polymers which structure varies according to the algal species [18]. Their biological activities depend on chemical structure, molecular weight and chain conformation [19]. The most abundant SP found in marine algae are fucoidan and laminarans of brown algae, carrageenan of red algae and ulvan of green algae [20] [21]. Fucoidans have been reported by their antioxidant, anti-inflammatory, anti-allergic, anti-tumour, anti-obesity, anti-coagulant, anti-viral, anti-hepatopathy, anti-uropathy and anti-renalpathy effects. Plus, they are widely available commercially from various cheap sources when compared to other SP. Hence, they have been more and more investigated to develop functional foods [22], for disease prevention and health promotion [23]. Fucoindans from seaweeds are heterogenic compounds, being a mixture of structurally related polysaccharides with certain variations of the content of carbohydrate units and non-carbohydrate substituents [24]. They are essentially composed of fucose and sulphate, and also contain other monosaccharides like mannose, galactose, glucose, xylose, etc., and uronic acids [23].

Another interesting feature of marine algae is their richness in NP [13] which can be classified into chlorophylls, carotenoids and phycobiliproteins. Chlorophylls are greenish lipid-soluble NP with a porphyrin ring [25]. The most important one is chlorophyll $a$, [26] but there is also chlorophyll b, c, and d [27]. Carotenoids have an important function, in algae, of inactivating reactive oxygen species (ROS). They are linear polyenes [28] that can be classified into carotenes (unsatured hydrocarbons) and xanthophylls (where one or more functional groups contain oxygen) [29]. Among carotenoids, fucoxanthin is a very visible one [30], with an unusual allenic bond and a 5,6-monoepoxide [31]. Phycobiliproteins are water soluble fluorescent proteins [29] that can be divided into phycocyanins, allophycocyanins and phycoerythtins [32] [33].

Marine brown algae contain a variety of phloroglucinol-based polyphenols as phlorotannins. These compounds consist of phloroglucinol (1,3,5-trihydroxybenzene) monomer units, linked to each other in various ways [34]. According to the means of linkage, phlorotannins can be classified into fuhalols and phlorethols (ether linkage), fucols (phenyl linkage) fucophloroethols (ether and phenyl linkage) and eckols (dibenzodioxin linkage) [35]. 


\section{Bioactivities}

\subsection{Antioxidant Properties}

The use of oxygen, in normal metabolism, leads to the production of reactive oxygen species (ROS) [36], which can react with molecules in living cells such as lipids, sugars, amino acids and nucleotides [37]. The endogenous antioxidants such as superoxide dismutase, catalase and glutathione peroxidase and non-enzymatic antioxidants such as vitamine C, $\alpha$-tocopherol and selenium are very important. They reduce these oxidant reactions [38] that can be highly toxic and deleterious to cells and tissues [36]. The imbalance between antioxidants and oxidants, in favour to oxidants, results in health issues such as cancer, neurodegenerative disease, autoimmune conditions [39]-[41], cardiovascular disease, hypertension, diabetes mellitus, inflammatory disease and aging [42]. There is an interest in the food and pharmaceutical industry for the development of antioxidants from natural sources as safe alternatives of synthetic commercial antioxidants [23].

It has also been proposed that oxidative damage determines life span. However, even though multiple studies support the association between age-related disorders and oxidative damage, the data does not support or remains inconclusive, whether it determines life span [43].

Moreover, the balance between oxidants and antioxidants is an important determinant of immune cell function. Optimal amounts of antioxidants are needed for maintenance of immune response, particularly in aged people as age-associated dysregulation of immune response is well documented. There is an age-related increase in free radical formation and lipid peroxidation, which contributes, in part, to this phenomenon [44].

Generally, the consumption of seaweed increases the activity of superoxide dismutase, glutathione peroxidise and sometimes catalase, which are endogenous antioxidant enzymes [45]-[47].

Sulphated polysaccharides from algae have potential antioxidant activity. Fucoidan, laminaran and alginic acid in particularly, have been shown as potent antioxidants [48]-[50]. It has been reported in vivo antioxidant activity of SP from Porphyra haitanensis in aging mice [51]. Fucoidan from Fucus vesiculosus prevented the formation of superoxide radicals, hydroxyl radicals and lipid peroxidation [52]. The ones from Laminaria japonica have shown to possess scavenging capacities on superoxide radical and hypochlorous acid (HOCl) [53] and protective effect on LDL oxidation induced by the radicals AAPH and AMNV [54]. Hipochlorous acid is a powerful oxidant. It contributes to the microbial killing which leads to the injury of host tissue and triggers severe inflammation disorders [55]. Moreover, in an in vivo experiment on diabetic mice, fucoidans from this specie prevented the increase of lipid peroxidation in serum, liver and spleen [56]. These results on fucoidans indicate their potential for preventing the free radical-mediated diseases [23].

Marine brown algae also accumulate phloroglucinol-based polyphenols as phlorotannins [35]. These compounds have strong antioxidant activities against free radical 
mediated oxidation damage. This activity can be due to the scavenging of radicals formed during peroxidation, the scavenging of oxygen-containing compounds or to the metal-chelating activity [35]. Ecklonia cava's phlorotannins were isolated for the evaluation of their antioxidant properties. The results show that most of the tested phlorotannins derivatives have significant total antioxidant activity in comparison to tocopherol. They also presented potential against DPPH, hydroxyl, superoxide and peroxyl radicals when their scavenging activity was tested. The cellular ROS inhibition assay and the membrane protein oxidation assay confirmed these results. Based on this study the authors claim that the phlorotannins from E. cava "have noteworthy potential for application as antioxidants in functional foods" [55].

Furthermore, phlorotannins from Ecklonia kurome, Ecklonia bicyclis and Hizikia fusiformes also revealed potent antioxidant activity and protective effect against hydrogen peroxidase-induced cell damage [57]-[59].

As described above, natural pigments, including fucoxanthin, phycoerithrobilin, chlorophyll $a$ and their derivatives, present antioxidant activities [13]. Chlorophyll $a$ reacts with peroxyl radicals leading to inactive products [60] [61]. Its derivatives have shown more potent antioxidant activity [60] and chlorophyll $b$ derivatives even more [62]. Fucoxanthin is a carotenoid which colors brown algae and diatoms [13]. Its oral administration to broiler chicks improved plasma antioxidant status [63]. Moreover, it was reported that fucoxanthin has cytoprotective effect against ROS formation induced by $\mathrm{H}_{2} \mathrm{O}_{2}$ in vitro [64].

Finally, some research works have focused on antioxidant properties of protein hydrolysates and peptides. Antioxidative effects of water-soluble, protease enzymatic extracts of marine edible brown seaweeds were reported. This included Ecklonia cava, Scytosiphon lomentaria, Ishige okamurae, Sargassum fullvelum, Sargasum horneri and Sargassum thunbergii. The enzymatic extracts of $E$. cava were the ones to scavenge DPPH free radicals more effectively. The highest inhibitory capacity of lipid peroxidation in linoleic acid was observed in alcalase extract of $E$. cava and neutrase extract of $S$. lomentaria [65]. In another study, $S$. lomentaria showed strong ROS scavenging activities after being hydrolysed by proteases [66]. In addition, enzyme assisted extractions (EAEs) from Palmaria palmate, a red algae, exhibited the greatest scavenging activities against DPPH and peroxyl radicals when treated with proteases than carbohydrases [67]. EAEs of Undaria pinnatifida, have also exhibited strong scavenging activities against DPPH and hydroxyl radicals, when treated with proteases [68]. Several studies have confirmed that low molecular weight hydrolysates have more potency to possess ROS scavenging activities than the high weight ones [69]. Pepsin hydrolysate from Chorella vulgaris protein waste showed potent antioxidant activity. The purified peptide from algal protein has shown highersuperoxide radical scavenging activities when compared to standard antioxidants. Furthermore, moderate antioxidative and scavenging effects were reported against DPPH radicals [70]. Hence, antioxidative protein hydrolysates, peptides or amino acids from marine algae may be potential sources to control various oxidative processes. However, due to the diversities of in vitro assay 
systems and inconsistency in the conditions used to evaluate their antioxidative capacity, it is difficult to compare the results from different studies [71].

\subsection{Anticancer Activity}

The likelihood of developing cancer increases with age, for both men and women, with only a small proportion known to be inherited [72] (WCRF, 1997).

Seaweeds regular intake was associated with lower risk of: rectal cancer [73] as well as benign and neoplasis cancer risk [74] [75]; and human breast cancers [76] with suppressive effects on the development of benign and cancer neoplasis [77].

Free radicals induce the formation of cancer cells in human body and so, oxidative damage is an important contributor in carcinogenesis. Hence, compounds with radical scavenging activity, such as the NP [13], SP [17] and phlorotannins [35] can be used indirectly to reduce cancer formation [13].

Phlorotannins derivatives from E. cava, such as fucodiphloroethol G, dieckol, ekol and phlorofucofurofuroeckol, demonstrated cytotoxic effect on human cancer cell lines including HT1080 (fibrosarcoma cell line), AS49 (lung cancer cell line) and HT-29 (human colon adenocarcinoma grade II). However, they were less cytotoxic to human normal lung fibroblasts [78]. Dioxinodehydroeckol, another phlorotannin derivative also from E. cava, reduced the growth of human breast cancer cells (MCF-7) by induction of apoptosis [79].

Regarding NPs, chlorophyll and its derivatives presented in vitro antimutagenic effect against numerous dietary and environmental mutagens [80]. Lutein, $\beta$-carotene and chlorophyll a from Porphyra exhibited anti-mutagenic activity in bacterial Salmonella typhimurium [81]. Other NPs studied for their anticancer qualities were the carotenoids. Adult T-cell leukaemia is an incurable and fatal malignancy of $\mathrm{T}$ lymphocytes caused by human T-cell leukaemia virus type 1 infection [13]. Fucoxanthin presented anti-adult T-cell leukemic effects [82] as it induced apoptosis on human leukaemia cells (HL-60) [83] [84]. Moreover, fucoxanthin demonstrated anti-proliferative effects and induced apoptosis in human colon cancer cells (caco-2, HT-29 and DLD-1) [85] and induced apoptosis in human prostate cancer cells [86] [87] (PC-3, DU145 and LNCaP). Exposure to this compound also decreases the level of apoptosis suppressing protein (Bcl-2) [86].

Angiogenesis is the process of new blood vessels formation from a pre-existing vasculature [88]. This can either occur under physiological or pathological conditions such as inflammatory diseases, rheumatoid arthritis and tumour metastasis where the chronic unregulated angiogenic state can help spreading of the diseases [89]. Hence, preventing angiogenesis is a promising approach in the prevention of angiogenic-related diseases [13] such as cancer, where the active supply of blood to tumour tissue is reduced [90] [91]. Fucoxanthin suppressed the differentiation of endothelial progenitor cells, of the umbilical vein, into endothelial cells involving new blood vessels formation [92]. In an in vivo and ex vivo angiogenesis assay, using a rat aortic ring, fucoxanthin and fucoxanthinol suppressed microvessel outgrowth [92]. Siphonaxanthin, from the algae Codium 
fragile, also possess anti-angiogenic effect, comparable with fucoxanthin [93].

SPs are also radical scavenging compounds but their anticancer activity goes beyond that [17]. They have demonstrated antiproliferative activity in cancer cell lines in vitro and inhibitory activity of tumour growth in mice [19] [48] and anti-metastatic activity [94]. This last activity is achieved by blocking the interaction between cancer cells and basement membranes [19] [94]. However, the exact mechanism of action by which tumour cell proliferation and tumour cell adhesion to various substrates are inhibit is not yet completely understood [17]. Porphyrans, the SPs from Porphyra, induced in vitro apoptosis in AGS human gastric cancer cells, in a dose-dependent manner, without affecting the growth of normal cells [95].

Fucoidans present anti-tumour activity due to their ability to inhibit the proliferation of tumour cells; stimulate the apoptosis of tumour cells; block tumour cells metastasis; enhance immune responses 23 and their anti-angiogenic effect [90] [91]. The anti-proliferative activity was observed with Cladosiphon okamuranus fucoidans, in human leukemic monocyte lymphoma cell line (U 937). This was caused by inducing apoptosis via caspase-3 and 7 activation dependent pathways [96]. The growth of peripheral blood mononuclear cells of adult T-cell leukaemia patients and human T-cell leukaemia virus (HTLV) type 1-infected T-cell lines was also inhibited. However, the normal peripheral blood mononuclear cells were not. The apoptosis of HTLV-1-infected T-cell lines was achieved by down regulation of cellular inhibitor of apoptosis protein 2 [97]. Moreover, MDA-MB-231 breast carcinoma cell adhesion to platelets was blocked by fucoidans from L. saccharina, L. digitata, Fucus serratus, Fucus distichus and Fucua vesiculosus. This might have critical implications in tumour metastasis [23]. Antimetastatic activity was also observed with fucoidan from Fucus evanescens, when 10 $\mathrm{mg} / \mathrm{Kg}$ of it was administrated to $\mathrm{C} 57 \mathrm{Bl} / 6$ mice with Lewis lung adenocarcinoma [98]. A variety of sulphated polysaccharides, such as fucoidans and heparin, reduced lung metastasis resulting from the intravenous injection of cells from the rat mammary adenocarcinoma 13762 MTA [99]. Finally, fucoidan increases the quantity of macrophages [100]; mediates the destruction of the tumour through type 1 T-helper (Th1) cells and NK response [101] and activates lymphocytes and macrophages mediated by production of free radicals (nitric oxide and $\mathrm{H}_{2} \mathrm{O}_{2}$ ) and cytokines-tumour necrosis factor $\alpha$ (TNF- $\alpha$ ) and interleukin-6(IL-6) [102]. This enhancement of immune responses inhibits tumour growth and metastatic process [100].

\subsection{Effects on Inflammation and Immunomodulating Activity}

The immune system reduces its responsiveness with age, in a process known as immunosenescence [103]. The dysregulation of the immune response makes older people less capable of fighting disease [103]-[105], reduces the effectiveness of vaccination [103] [104] and predisposes them to higher incidences of infectious, autoimmune and inflammatory diseases [106].

Inflammation is an important aspect of host response. Nonetheless, it also contributes to the pathogenesis of many chronic diseases such as chronic asthma, rheumatoid 
arthritis, multiple sclerosis, inflammatory bowel disease, psoriasis [107], certain cancers and neurodegenerative diseases [13]. As such, when inflammation is excessive or prolonged, it can be harmful [107].

Macrophages are a major source of pro-inflammatory mediators like nitric oxide (NO), prostaglandin E2 (PGE2), and pro-inflammatory cytokines like TNF- $\alpha$, (IL-6), interleukin-1 $\beta$ (IL-1 $\beta$ ) and ROS. NPs' anti-inflammatory activity is based on modulation of macrophages function [108]. However, there are not many reported studies [13]. Pheophytin a, from E. prolifera, suppressed the inflammatory response in mouse macrophages [109]. Fucoxanthin exhibits potent anti-inflammatory activity in vitro and in vivo, in response to bacterial lipopolysaccharides (LPS) [110]. The treatment with this compound reduced the production of NO and PGE2 by inhibiting NO synthase (iNOS) and cyclooxygenase 2 (COX-2) expressions. Moreover, the release and expression of TNF- $\alpha$, IL- 6 and IL- $\beta$ were attenuated in a dose-dependent manner [111]. The anti-inflammatory effects were due to the suppression of nuclear factor kappa $\mathrm{B}(\mathrm{NF}-\mathrm{kB})$ and the phosphorylation of mitogen activated protein Kinases (MAPKs) [112].

During inflammatory diseases, including chronic wound, chronic leg ulcers and rheumatoid arthritis, connective tissue is destructed. This occurs because of the continuous supply of inflammatory cells and exacerbated production of inflammatory cytokines and matrix proteinases. Fucoindan from Ascophyllum nodosum was able to modulate connective tissue proteolysis [113].

Fucoidan from E. cava inhibit NO and PGE2 production, by suppressing the expression of iNOS and COX-2, in a dose-dependent manner [114] [115]. E. cava also suppressed TNF- $\alpha$, IL- 6 and IL- $1 \beta$ in LPS stimulated murine microglia (BV2) cells. This was achieved by blocking NF-kB and MAPKs activation [116] [117]. Moreover, fucoidans from Laminaria japonicaon and from Fucus vesiculosus presented anti-inflammatory activity. The first ones inhibited NO production and expression, and the others inhibited the excessive production of NO and PGE2 by suppressing the expression of iNOS and COX-2 [115].

Selectin family contributes to the interactions of leucocytes and platelets at the side of vascular injury. This enhances inflammatory reactions during arterial response to injury [118]. Fucoindan inhibit the interaction of selectin with its ligands [119]-[122], reducing inflammation process at early stages [22].

Although these results indicate that fucoidans have anti-inflammatory activities, others SP may act on the opposite direction. Carrageenan, from red marine algae, is a potent inflammatory in rodents. It leads to the production of TNF- $\alpha$ by mice leucocytes, in response to bacterial LPS [123]. Furthermore, some carrageenans induce potent macrophage activation [124] while others carrageenans and fucoidans inhibit macrophage functions [125] [126]. Moreover, SP from Porphyra yezoensis and Garcilaria verrucosa stimulate phagocytosis and respiratory burst in mouse macrophages in vitro and in vivo [127] [128]. In addition, SP from Ulva rigida induced an increase in the expression of several chemokines and interleukins and the production of nitrite. It also stimulated macrophage secretion of $\mathrm{PGE}_{2}$ and induced an increase in COX-2 and nitric 
oxide synthase-2 (NOS-2) expression [129].

Bioactive peptides have also been reported for the induction and stimulation of the immune system [130]. Most peptides are encrypted in the parent proteins in the algae, and during gastrointestinal digestion, they might be released [131]. Hence, protein hydrolysates have been widely used to enhance the nutritional and functional values of the food [132]. Protein hydrolysate from the microalga Chlorella vulgaris was obtained by the pancreatic enzyme. Its oral administration to mice, during 8 days after 3 days of fasting period, resulted in an increase up to $128 \%$ of the lymphocyte pool when compared to the control group. Moreover, mononuclear phagocyte system and both humoral and cell mediated immune functions were increased. This included an increase on the functional activities of macrophages, a stimulation of T-dependent antibody responses and reconstitution of delayed-type hypersensitivity (DTH) [133]. The hydrolyzate from E. cava, obtained by protease, enhanced the proliferation effect of splenocytes in mice, including lymphocytes, monocytes and granulocytes. In addition, the number of $\mathrm{CD}^{+} \mathrm{T}$ cells, $\mathrm{CD} 8^{+} \mathrm{T}$ cells and $\mathrm{CD} 45 \mathrm{R} / \mathrm{B} 220^{+} \mathrm{B}$ cells were markedly increased compared to controls which were untreated. Furthermore, the mRNA expression and production of Th- 1 type cytokines, like TNF- $\alpha$ and INF- $\gamma$, were down regulated and thus Th-2 type cytokines, including IL-4 and IL-10, were up regulated [134].

\subsection{Anti-Obesity Activity}

Obesity is a chronic metabolic disorder that might be defined as excessive body weight in the form of fat. It is caused by an imbalance between body intake and expenditure. Obesity is associated with various diseases particularly heart disease, type 2 diabetes, obstructive sleep apnea, certain types of cancer and osteoarthritis [135]-[137]. Furthermore, this disorder keeps increasing in many industrialized and developing countries, affecting teen and seniors [138]. Until the age of 75, being obese or overweight is more prevalent than malnutrition [139]. However, over the age of 75, eating less in order to lose weight could result in nutrient deficiencies which may cause more problems than being overweight [140].

Fucoxanthin from Undaria pinnatifida and fucoxanthinol inhibited the differentiation of 3T3-L1 preadipocytes into adipocytes [141]. This effect might be achieved by down-regulation of adipogenic transcription factors, such as peroxisome proliferatoractivated receptor- $\gamma$ [13]. Moreover, fucoxanthin and neoxantin were reported to suppress adipocyte differentiation [142]. Uncoupling protein 1 (UCP1) is a mitochondrial protein that dissipates energy through uncoupling of oxidative phosphorylation. This leads to the production of heat instead of ATP [143]. A nutrigenomic revealed that fucoxanthin induces UCP1 expression on white adipose tissue, which is the predominate type of adipose tissue in humans. However, UCP1 is known to be exclusively in brown adipose tissue [13] [143]. Nonetheless, further efforts are needed to better understand the molecular mechanisms and the intracellular signaling pathways underlying UCP1 induction by fucoxhanthin [13]. According to these results, NPs are potential candidates to be used, by food and pharmaceutical, in treatment or prevention of obesity 
[13].

Fucoidan from Fucus vesiculosus increased the expressed protein levels of total hormone sensitive lipase (HSL) and of phosphorylated-HSL, its activated form. It also decreased insulin-induced 2-deoxy-D-[3H] glucose uptake. These effects lead to stimulation of lipolysis. Hence, fucoidan from Fucus vesiculosus inhibit lipid accumulation through the regulation of lipolysis in 3T3-L1 adipocytes [144].

The high soluble dietary fiber content of seaweeds helps slow down digestion and caloric absorption and moderate appetite through delaying gastric emptying and absorption in the small intestine [145]. However, this is difficult to prove in humans [14].

\subsection{Anti-Diabetic Activity}

Type 2 diabetes mellitus (DM) is more common in older people [146]. One of the reasons is because aging its associated with a reduced ability to metabolize glucose from food [147]. Moreover, it is related to lifestyle and obesity, particularly central adiposity [146]. In older people, increased abdominal obesity can cause metabolic changes leading to insulin resistance, which is a risk factor for the development of type 2 DM [148].

Diet is essential in the treatment of diabetes and proper nutrition is essential to prevent complications [149]. However, the compliance with diabetic recommendations is low, because it is not easy to follow [150]. Recently, functional foods have appeared as new means to help maintain proper nutrition, in cases of chronic diseases such as diabetes [151].

Dietary fucoxanthin has been reported for its anti-obesity and anti-diabetic effects [152]-[154]. It attenuates the weight gain of white adiposite tissue (WAT) of diabetic/ obese KK-A(y) mice. When these mice were fed with fucoxanthin, mRNA expression of monocyte chemoattractant protein-1 (MPC-1) and TNF- $\alpha$, in perigonadal and mesenteric WATS, were markedly reduced compared to control mice. MPC-1 and TNF- $\alpha$ are considered to induce insulin resistance. These parameters were not altered on lean C57BL/6J mice. In addition, fucoxanthin also decreased mRNA expression levels of interleukin-6 (IL-6) and plasminogen activator inhibitor-1 in WAT of KK-A(y) mice [153].

Fucoxanthiol, the metabolite of fucoxanthin in WAT, attenuated TNF- $\alpha$ induced, MPC-1 and IL-6 mRNA overexpression. According to these results, fucoxanthin regulates $\mathrm{m}$ RNA expression of inflammatory adipocytokines involved in insulin resistance on diabetic/obese KK-A(y) mice but not on lean C57BL/6J mice [152].

On another study, mice were fed with $0.2 \%$ of fucoxanthin for 4 weeks. This diet attenuated the gain of WAT in KK-A (y) mice, with increasing uncoupling protein-1 (UCP1) expression when compared to the control mice. The blood glucose and plasma insulin concentrations were also decreased in KK-A(y) mice. Finally, mRNA expressions of leptin and TNF- $\alpha$ were down-regulated [153].

Wakame (Undaria pinnatifida) is seaweed with fucoxanthin-rich lipids (WLs). The anti-obesity and anti-diabetic effects of these compounds were examined on mice with high fat (HF) diet-induced obesity. The HF diet followed by WL diet (HF-WL diet) 
suppressed body weight and WAT gain. The hyperglycemia, hyperinsulinemia and hyperleptinemia, that were also a result of HF diet, were normalized in FH-WL diet fed group. In addition, the FH-WL diet promoted mRNA expression of $\beta$-3 adrenergicreceptor in WAT, and glucose transporter 4 (GLUT-4) mRNA in skeletal muscle tissue. Given these results, the authors claim that there is a "biochemical and nutritional basis for the application of fucoxanthin-rich WLs as functional foods to prevent obesity and diabetes-related disorders" [154].

Postprandial hyperglycemia represents a direct and independent risk for cardiovascular disease [155] and it is implicated in the development of type 2 diabetes. Furthermore, it can induce the elevation of glycated haemoglobin ( $\mathrm{HbAlc}$ ), contributing to the development of macro and microvascular problems [156]. Postprandial hyperglycemia can be treated through delaying the digestion of carbohydrates [157]. This can be achieved by inhibiting enzymes responsible for carbohydrate digestion like $\alpha$-amylase and $\alpha$-glucosidase [158].

The extract from the brow algae ezoishige (Pelvetia babingtonni de Toni) inhibited the rat-intestinal $\alpha$-glucosidase in vitro. Moreover, its oral administration with sucrose significantly suppressed the postprandial elevation of the blood glucose level, compared with the control. According to these results and given the fact that ezoishige is an underutilized algae, it could be considered as a promising functional food material for controlling the blood glucose level, preventing and/or reducing the risk of diabetes and obesity [159]. Acophyllum nodosum and Grateloupia elliptica extracts also inhibited $\alpha$-glucosidase activity [160] [161].

Phlorotannins from Ecklonia cava, especially dieckol, were able to significantly inhibit rat-intestinal $\alpha$-glucosidase and porcine pancreatic $\alpha$-amylase [162]. Furthermore, phlorotannins are also inhibitors of aldose reductase. This enzyme catalyzes glucose to sorbitol in cells. This activity is important because the accumulation of sorbitol in cells leads to various chronic complications of diabetes like cataracts, neuropathy and retinopathy [35].

\subsection{Neuroprotective Effect}

Neurodegenerative diseases are expected to surpass cancer and be the second most common cause of death among elderly by 2040s [163] [164]. For this reason, a great deal of attention has been expressed regarding the effectiveness and the safeness of neuroprotective agents [8].

Marine algae have been reported to present biological activities and neuroprotective effects, including antioxidant, anti-neuroinflammatory, cholinesterase inhibitory activity and inhibition of neural death. For this reason, they have been recognized for their potential as neuroprotectors, as part of pharmaceuticals and functional foods [8].

The central nervous system presents high lipid content and high oxygen consumption, which makes it more sensitive to oxidative stress than other parts of our body [165]. Oxidative stress in the CNS involves excitotoxicity and apoptosis, which are the two main causes of neural death. Moreover, it has been implicated in the progression of 
neurodegenerative diseases such as Alzheimer's disease (AD), Parkinson's disease (PD), multiple sclerosis (MS), among others [166] [167]. The anti-oxidant activity of marine alga has been reported by different scientists and it has been already discussed. However, there are some studies, regarding this activity, that suggest that marine algae are useful candidates to protect specifically the CNS against oxidative degradation. Neorhodomela aculeate scavenged DPPH and completely suppressed lipid peroxidation induced by $\mathrm{H}_{2} \mathrm{O}_{2}$ in rat brain homogenate [168]. Halimeda incrassata and Bryothamnion were reported as potent ROS scavengers in mouse hypothalamic (GT1-7) cells [169]; Moreover, Fucoxanthin from wakame was able to attenuate cell damage in cortical neurons during hypoxia and oxygen reperfusion [170]. Because ROS generation is considered to occur after hypoxia and re-oxygenation, through which free radicals damage neurons, it may assume that fucoxanthin's neuroprotective is mainly based on its scavenging activity [13]. The same compound, isolated from $H$. fusiformis inhibited the expression of $\mathrm{N}$-myc and cell cycle progression of GOT0 cells, a human neuroblastoma cell line [171]. The phlorotannin dieckol was able to scavenge ROS production in murine microglia (BV2) cells [172]. Sulphated polysaccharides were also discussed for their anti-oxidant activity. However, its activity against oxidative stress in the CNS has not been demonstrated yet [8].

In order to use these compounds to slow down the progression of neurodegenerative diseases in populations that are at high risk, such as the elderly, it has to be determined if they can be used as prophylactic neuroprotective agents [8].

Inflammation is the pathophysiological mechanism underlying neurodegenerative diseases [173]. Although there are many cells that contribute to inflammation-mediated neurodegeneration, microglia is critical components of the immunological insult to neurons [174]. The activation of these immune cells leads to the production of proinflammatory and neurotoxic factors that are sufficient to induce neurodegeneration in a rat model. Moreover, their activation and excessive amounts of mediators release by microglia have been observed during the pathogenesis of PD, AD and MS [175] [176]. Among the mediators released by microglia, the most cytotoxic ones are NO and PGE2, in the innate response in the CNS [177] [178]. Furthermore, NO generated by iNOS causes injury and cell death of neuron and oligodendrocytes in the CNS and so it is implicated in the pathogenesis of many neurodegenerative diseases [177] [179] [180]. As described, some marine algae were reported to have anti-inflammatory effects, some of them regarding BV2 cells, NO and PGE2. $N$. aculeate decreased the production of NO and iNOS expression in interferon-gamma (INF- $\gamma$ ) stimulated BV2 cells [181]. The methanolic extracts of $U$. conglobata suppressed the expression of pro-inflammatory enzymes, iNOS and COX-2, which were responsible for the large production of NO and PGE2, respectively [182] [183]. However, further studies are needed, including clinical trials, regarding anti-neuroinflammatory activity [8].

Alzheimer's disease has been associated with a deficiency in the brain neurotransmitter acetylcholine (Ach) [184]. Therefore, inhibition of the enzyme that catalyzes the breakdown of Ach, acetylcholinesterase (AChE), may be a realistic approach to the 
symptomatic treatment [185]. Some algae have been reported for their AChE inhibitory activity such as Ecklonia stolonifera and Ishige okamurae. Some of the compounds involved were eckol, dieckol, 2-phloroeckol and 3-phloroeckol from the first algae and 6,6-bieckol from the other algae [186] [187].

Regarding neural death, fucoidan from Fucus vesiculosus have been reported for its capacity to protect rat cholinergic neural death induced by amyloid beta ${ }_{1-42}\left(\mathrm{~A} \beta_{1-42}\right)$ [188]. The treatment with fucoidan blocked the activation of caspase-9 and caspase-3, which may mediate the terminal stages of neural apoptosis [189]. Hence, inhibition of neural death by fucoidan may occur mainly through apoptotic inhibition [8].

\subsection{Other Biological Activities}

Seaweeds have a higher content in soluble dietary fibers than terrestrial plants [190]. Soluble fibers effects include water binding, fecal bulking and digestive transit time decrease, which benefits gut health [191] [192] and indirectly prevent colon cancer [193].

Dietary fibers also support the reduction of cholesterol levels. The Sp from Ulva pertusa reduced serum triglycerides (Tg), total cholesterol and low density lipoprotein cholesterol (LDL-cholesterol). It also increased high density lipoprotein (HDL-cholesterol) in mice. The anti-hyperlipidemic activity was related to the molecular weight of Ulvan fractions [193]. Moreover, porphyran from Porphyra Yezoensis reduced apolipoprotein B100 (ApoB100) secretion [194] which levels were positively related to cardiovascular disease [195]. The reduction of ApoB100 secretion is achieved mainly through the suppression of lipid synthesis in human liver derived cells [194].

Furthermore, fucoidan from Cladosiphon okamuranus was reported to protect gastic mucosa against acid and pepsin. Hence, it could be developed as a potential anti-ulcer ingredient in functional foods [196] [197].

\section{Conclusions}

Functional foods can be particularly important in older people. They can have a role in special nutrient intake and in reducing the risk of chronic conditions [6]. Algae can be a source of new compounds that could be used as functional ingredients [5]. They produce a great variety of biological active components that cannot be found in other organisms [12], and research reports on their therapeutic properties are numerous [5].

The studies suggest that NP [13], phlorotannins [36], SP [17] and proteins [130] from seaweeds, and microalgae have potential to be a part of new functional foods. However, further studies are needed, for example studies in human subjects, as in the case of SP [17], or large-scale controlled studies and human studies in order to investigate algae neuroprotective activities [8]. Moreover, once usefulness is demonstrated it will be necessary to consider other aspects as ingredients extraction and purification, their production at industrial scale, algae growing, among others [5].

\section{Acknowledgements}

The authors wish to thank to "Projeto Estratégico-RG-Centro-177-3717 da FCT" (Por- 
tugal).

\section{References}

[1] Roberfroid, M.B. (2000) Concepts and Strategy of Functional Food Science: The European Perspective. American Journal of Clinical Nutrition, 71, 1660S-4S.

[2] Palanca, V., Rodriguez, E., Señorans, J. and Reglero, G. (2006) Bases científicas para el desarrollo de productos cárnicos funcionales con actividad biológica combinada. Nutrición Hospitalaria, 21, 199-202.

[3] Roche, H.M. (2006) Nutrigenomics-New Approaches for Human Nutrition Research. Journal of the Science of Food and Agriculture, 86, 1156-1163. http://dx.doi.org/10.1002/jsfa.2484

[4] Diplock, A.T., Aggett, P.J., Ashwell, M., Bornet, F., Fern, E.B. and Roberfroid, M.B. (1999) Scientific Concepts of Functional Foods in Europe: Consensus Document. British Journal of Nutrition, 81, S1eS27.

[5] Plaza, M., Cifuentes, A. and Ibañéz E. (2008) In the Search of New Functional Food Ingredients from Algae. Trends in Food Science \& Technology, 19, 31-39. http://dx.doi.org/10.1016/j.tifs.2007.07.012

[6] Taylor, R. and Serra, V. (2013) Older People and Functional Foods. International Longevity Centre, London. www.ilcuk.org.uk

[7] Cannella, C., Savina, C. and Donini, L.M. (2009) Nutrition, Longevity and Behavior. Archives of Gerontology and Geriatrics, 49, 19-27.

http://dx.doi.org/10.1016/j.archger.2009.09.008

[8] Pangestuti, R. and Kim, SK. (2011) Neuroprotective Effects of Marine Algae. Marine Drugs, 9, 803-818. http://dx.doi.org/10.3390/md9050803

[9] Barrow, C. and Shahidi, F. (2007) Marine Nutraceuticals and Functional Foods. CRC Press, New York.

[10] Wijesekara, I. and Kim, S.K. (2010) Angiotensin-I-Converting Enzyme (ACE) Inhibitors from Marine Resources: Prospects in the Pharmaceutical Industry. Marine Drugs, 8, 10801093. http://dx.doi.org/10.3390/md8041080

[11] Wijesekara, I., Yoon, N.Y. and Kim, S.K. (2010) Phlorotannins from Ecklonia Cava (Phaeophyceae): Biological Activities and Potential Health Benefits. Biofactors. http://dx.doi.org/10.1002/biof.114

[12] Carlucci, M.J., Scolaro, L.A. and Damonte, E.B. (1999) Inhibitory Action of Natural Carrageenans on Herpes Simplex Virus Infection of Mouse Astrocytes. Chemoterapy, 45, 429436. http://dx.doi.org/10.1159/000007236

[13] Pangestuti, R. and Kim, Sk. (2011) Biological Activities and Health Benefit Effects of Natural Pigments Derived from Marine Algae. Journal of Functional Foods, 3, 255-266. http://dx.doi.org/10.1016/j.jff.2011.07.001

[14] Mohamed, S., Hashim, S.N. and Rahman, A. (2012) Seaweeds: A Sustainable Functional Food for Complementary and Alternative Therapy. Trends in Food Science and Techonology, 23, 83-69. http://dx.doi.org/10.1016/j.tifs.2011.09.001

[15] Heo, S.J., Hwang, J.Y., Choi, J.I., Han, J.S., Kim, H.J. and Jeon, Y.J. (2009) Diphlorethohydroxycarmalol Isolated from Ishige Okamurae, a Brown Algae, a Potent A-Glucosidase and Aamylase Inhibitor, Alleviates Postprandial Hyperglycemia in Diabetic Mice. European Journal of Pharmacology, 615, 252-256. http://dx.doi.org/10.1016/j.ejphar.2009.05.017

[16] Rhodes, C.J. (2009) Oil from Algae; Salvation from Peak Oil? Science Progress, 92, 39-90. 
http://dx.doi.org/10.3184/003685009X440281

[17] Wijesekara, I., Pangestuti, R. and Kim, S.K. (2011) Biological Activities and Potential Health Benefits of Sulfated Polysaccharides Derived from Marine Algae. Carbohydrate Polymers, 84, 14-21. http://dx.doi.org/10.1016/j.carbpol.2010.10.062

[18] Costa, L.S., Fidelis, G.P., Cordeiro, S.L., Oliveira, R.M., Sabry, D.A., Camara, R.B.G., et al. (2010) Biological Activities of Sulfated Polysaccharides from Tropical Seaweeds. Biomedicine and Pharmacotherapy, 64, 21-28. http://dx.doi.org/10.1016/j.biopha.2009.03.005

[19] Ye, H., Wang, K., Zhou, C., Liu, J. and Zeng, X. (2008) Purification, Antitumor and Antioxidant Activities in Vitro of Polysaccharides from the Brown Seaweed Sargassum pallidum. Food Chemistry, 111, 428-432. http://dx.doi.org/10.1016/j.foodchem.2008.04.012

[20] Campo, V.L., Kawano, D.F., da Silva, D.B. and Carvalho, I. (2009) Carrageenans: Biological Properties, Chemical Modifications and Structural Analysis-A Review. Carbohydrate Polymers, 77, 167-180. http://dx.doi.org/10.1016/j.carbpol.2009.01.020

[21] Chen, H., Yan, X., Lin, J., Wang, F. and Xu, W. (2007) Depolymerized Products of $\lambda$-Carrageenan as a Potent Angiogenesis Inhibitor. Journal of Agricultural and Food Chemistry, 55, 6910-6917. http://dx.doi.org/10.1021/jf070183+

[22] Li, B., Lu, F., Wei, X. and Zhao, R. (2008) Fucoidan: Structure and Bioactivity. Molecules, 13, 1671-1695. http://dx.doi.org/10.3390/molecules13081671

[23] Vo, T.S. and Kim, S.K. (2013) Fucoidans as a Natural Bioactive Ingredient for Functional Foods. Journal of Functional Foods, 5, 16-27. http://dx.doi.org/10.3390/molecules13081671

[24] Cumashi, A., Ushakova, N.A., Preobrazhenskaya, M.E., D’Incecco, A., Piccoli, A., Totani, L., Tinari, N., Morozevich, G.E., Berman, A.E., Bilan, M.I., Usov, A.I., Nadezhda, E., Grachev, A.A., Sanderson, C.J., Kelly, M., Rabinovich, G.A. and Iacobelli, S. (2007) A Comparative Study of the Anti-Inflammatory, Anticoagulant, Antiangiogenic, and Antiadhesive Activities of Nine Different Fucoidans from Brown Seaweeds. Glycobiology, 17, 541-552. http://dx.doi.org/10.1093/glycob/cwm014

[25] Ferruzzi, M.G. and Blakeslee, J. (2007) Digestion, Absorption, and Cancer Preventative Activity of Dietary Chlorophyll Derivatives. Nutrition Research, 27, 1-12.

http://dx.doi.org/10.1016/j.nutres.2006.12.003

[26] Holdt, S.L. and Kraan, S. (2011) Bioactive Compounds in Seaweed: Functional Food Applications and Legislation. Journal of Applied Phycology, 23, 543-597.

http://dx.doi.org/10.1007/s10811-010-9632-5

[27] Larkum, A.W.D. and Kühl, M. (2005) Chlorophyll $d$ : The Puzzle Resolved. Trends in Plant Science, 10, 355-357. http://dx.doi.org/10.1016/j.tplants.2005.06.005

[28] Ioannou, E. and Roussis, V. (2009) Natural Products from Seaweeds. In: Osbourn, A.E. and Lanzotti, V., Eds., Plant-Derived Natural Products, Springer-Verlag, New York, 51-81. http://dx.doi.org/10.1007/978-0-387-85498-4 2

[29] Sousa, I., Batista, A.P., Raymundo, A. and Empis, J. (2006) Rheological Characterization of Coloured Oil-in-Water Food Emulsions with Lutein and Phycocyanin Added to the Oil and Aqueous Phases. Food Hydrocolloids, 20, 44-52. http://dx.doi.org/10.1016/j.foodhyd.2005.02.009

[30] Matsuno, T. (2001) Aquatic Animal Carotenoids. Fisheries Science, 67, 771-783. http://dx.doi.org/10.1046/j.1444-2906.2001.00323.x

[31] Terasaki, M., Hirose, A., Narayan, B., Baba, Y., Kawagoe, C., Yasui, H., et al. (2009) Evaluation of Recoverable Functional Lipid Components of Several Brown Seaweeds (Phaeophyta) from Japan with Special Reference to Fucoxanthin and Fucosterol Contents. Journal of Phycology, 45, 974-980. http://dx.doi.org/10.1046/j.1444-2906.2001.00323.x 
[32] Bogorad, L. (1995) Phycobiliproteins and Complementary Chromatic Adaptation. Annual Review of Plant Physiology, 26, 369-401. http://dx.doi.org/10.1146/annurev.pp.26.060175.002101

[33] Glazer, A.N. (1994) Phycobiliproteins-A Family of Valuable, Widely Used Fluorophores. Journal of Applied Phycology, 6, 105-112. http://dx.doi.org/10.1007/BF02186064

[34] Singh, I.P. and Bharate S.B. (2006) Phloroglucinol Compounds of Natural Origin. Natural Product Reports, 23, 558-591. http://dx.doi.org/10.1039/b600518g

[35] Li, Y.X., Wijesekara, I., Li, Y. and Kim, S.K. (2011) Phlorotannins as Bioactive Agents from Brown Algae. Process Biochemistry, 46, 2219-2224. http://dx.doi.org/10.1039/b600518g

[36] Halliwell, B. (1991) Reactive Oxygen Species in Living Systems: Source, Biochemistry and Role in Human Disease. The American Journal of Medicine, 91, S14-S22.

[37] Halliwell, B. and Gutteridge, M.C. (1985) The Chemistry of Oxygen Radicals and Other Oxygen-Derived Species. In: Halliwell, B. and Gutteridge, J.M.C., Eds., Free Radicals in Biology and Medicine, Clarendon Press, Oxford, 20-66.

[38] Halliwell, B. and Gutteridge, J.M.C. (2007) Free Radicals in Biology and Medicine. $4^{\text {th }}$ Edition, Oxford University Press, Oxford, 230-240.

[39] Halliwell, B. (1987) Oxidants and Human Disease: Some New Concepts. The FASEB Journal, 1, 358-364.

[40] Gutteridge, M.C. (1994) Hydroxyl Radicals, Iron, Oxidative Stress, and Neurodegeneration. Annals of the New York Academy of Sciences, 54, 288-295.

[41] Feig, D.I., Reid, T.M. and Loeb, L.A. (1994) Reactive Oxygen Species in Tumorigenesis. Cancer Research, 54, 1890-1894.

[42] Valko, M., Leibfritz, D., Mancol, J., Cronin, M.T.D., Mazur, M. and Telser, J. (2007) Free Radicals and Antioxidants in Normal Physiological Functions and Human Disease. The International Journal of Biochemistry \& Cell Biology, 39, 44-84. http://dx.doi.org/10.1016/j.biocel.2006.07.001

[43] Muller, F.L., Lustgarten, M.S., Jang, Y., Richardson, A. and Remmen, H.V. (2007) Trends in Oxidative Aging Theories. Free Radical Biology \& Medicine, 43, 477-503. http://dx.doi.org/10.1016/j.freeradbiomed.2007.03.034

[44] Meydani, S.N., Wu, D., Santos, M.S. and Hayec, M.G. (1995) Antioxidants and Immune Response in Aged Persons: Overview of Present Evidence. The American Journal of Clinical Nutrition, 62, 462-476S.

[45] Matanjun, P., Mohamed, S., Mustapha, N.M., Muhammad, K. and Cheng, H.W. (2008) Antioxidant Activities and Phenolics Content of Eight Species of Seaweeds from North Borneo. Journal of Applied Phycology, 20, 367-373. http://dx.doi.org/10.1007/s10811-007-9264-6

[46] Yuan, Y.V. and Walsh, N.A. (2006) Antioxidant and Antiproliferative Activities of Extracts from a Variety of Edible Seaweeds. Food and Chemical Toxicology, 44, 1144-1150. http://dx.doi.org/10.1016/j.fct.2006.02.002

[47] Zhang, Q.B., Li, N., Liu, X.G., Zhao, Z.Q., Li, Z.E. and Xu, Z.H. (2004) The Structure of a Sulfated Galactan from Porphyra haitanensis and Its in Vivo Antioxidant Activity. Carbohydrate Research, 339, 105-111. http://dx.doi.org/10.1016/j.fct.2006.02.002

[48] Rocha de Souza, M.C., Marques, C.T., Dore, C.M.G., Ferreira da Silva, F.R., Rocha, H.A.O. and Leite, E.L. (2007) Antioxidant Activities of Sulphated Polysaccharides from Brown and Red Seaweeds. Journal of Applied Phycology, 19, 153-160. http://dx.doi.org/10.1007/s10811-006-9121-Z 
[49] Ruperez, P., Ahrazem, O. and Leal, A. (2002) Potential Antioxidant Capacity of Sulphated Polysaccharides from the Edible Marine Brown Seaweed Fucus vesiculosus. Journal of Agricultural and Food Chemistry, 50, 840-845. http://dx.doi.org/10.1021/jf0109080

[50] Wang, J., Zhang, Q., Zhang, Z. and Li, Z. (2008) Antioxidant Activity of Sulphated Polysaccharide Fractions Extracted from Laminaria japonica. International Journal of Biological Macromolecules, 42, 127-132. http://dx.doi.org/10.1016/j.ijbiomac.2007.10.003

[51] Zhang, Q., Li, N., Zhou, G., Lu, X., Xu, Z. and Li, Z. (2003) In Vivo Antioxidant Activity of Polysaccharide Fraction from Porphyra haitanensis (Rhodephyta) in Aging Mice. Pharmacological Research, 48, 151-155. http://dx.doi.org/10.1016/S1043-6618(03)00103-8

[52] Micheline, R.S., Cybelle, M., Celina, G.D., Fernando, F.S., Hugo, O.R. and Edda, L. (2007) Antioxidant Activities of Sulfated Polysaccharides from Brown and Red Seaweeds. Journal of Applied Phycology, 19, 153-160. http://dx.doi.org/10.1007/s10811-006-9121-z

[53] Zhao, X., Xue, C.H., Cai, Y.P., Wang, D.F. and Fang, Y. (2005) The Study of Antioxidant Activities of Fucoidan from Laminaria japonica. High Technology Letters, 11, 91-94.

[54] Zhao, X., Wang, J.F. and Xue, C.H. (2011) The Inhibitory Effects of Fucoidans from Laminaria japonica on Oxidation of Human Low-Density Lipoproteins. Advanced Materials Research, 236-238, 2067-2071.

http://dx.doi.org/10.4028/www.scientific.net/AMR.236-238.2067

[55] Li, Y., Qian, Z.J., Ryu, B., Lee, S.H., Kim, M.M. and Kim, S.K. (2009) Chemical Components and Its Antioxidant Properties in Vitro: An Edible Marine Brown Algae, Ecklonia cava. Bioorganic \& Medicinal Chemistry, 17, 1963-1973.

http://dx.doi.org/10.1016/j.bmc.2009.01.031

[56] Li, D.Y., Xu, R.Y., Zhou, W.Z., Sheng, X.B., Yang, A.Y. and Cheng, J.L. (2002) Effects of Fucoidan Extracted from Brown Seaweed on Lipid Peroxidation in Mice. Acta Nutrimenta Sinica, 24, 389-392.

[57] Kang, K.A., Lee, K.H., Chae, S., Zhang, R., Jung, M.S., Lee, Y., et al. (2005) Eckol Isolated from Ecklonia cava Attenuates Oxidative Stress Induced Cell Damage in Lung Fibroblast Cells. FEBS Letters, 579, 6295-6304. http://dx.doi.org/10.1016/j.febslet.2005.10.008

[58] Kang, K.A., Lee, K.H., Chae, S.W., Koh, Y.S., Yoo, B.S., Kim, J.H., et al. (2005) Triphlorethol-A from Ecklonia cava Protects V79-4 Lung Fibroblast against Hydrogen Peroxide Induced Cell Damage. Free Radical Research, 39, 883-892. http://dx.doi.org/10.1080/10715760500161165

[59] Kang, K.A., Lee, K.H., Chae, S., Zhang, R., Jung, M.S., Ham, Y.M., et al. (2006) Cytoprotective Effect of Phloroglucinol on Oxidative Stress Induced Cell Damage via Catalase Activation. Journal of Cellular Biochemistry, 97, 609-620. http://dx.doi.org/10.1002/jcb.20668

[60] Cahyana, H. (1993) Antioxidative Activity of Porphyrin Derivatives. Bioscience, Biotechnology, and Biochemistry, 57, 680-681. http://dx.doi.org/10.1271/bbb.57.680

[61] Tutour, B.L., Brunel, C. and Quemeneur, F. (1996) Effet de synergie de la chlorophylle a sur les proprietes antioxydantes de la vitamine E. New Journal of Chemistry, 20, 707-721.

[62] Lanfer-Marquez, U.M., Barros, R. and Sinnecker, P. (2005) Antioxidant Activity of Chlorophylls and Their Derivatives. Food Research International, 38, 885-891. http://dx.doi.org/10.1271/bbb.57.680

[63] Sasaki, K., Ishihara, K., Yamazaki, M., Nakashima, K., Abe, H., Oyamada, C., et al. (2010) Oral Administration of Fucoxanthin Increases Plasma Fucoxanthinol Concentration and Antioxidative Ability and Improves Meat Color in Broiler Chicks. The Journal of Poultry Science, 47, 316-320. http://dx.doi.org/10.2141/jpsa.010019 
[64] Heo, S., Ko, S., Kang, S., Kang, H., Kim, J., Kim, S., et al. (2008) Cytoprotective Effect of Fucoxanthin Isolated from Brown Algae Sargassum siliquastrum against $\mathrm{H}_{2} \mathrm{O}_{2}$-Induced Cell Damage. European Food Research and Technology A, 228, 145-151.

[65] Heo, S.J., Lee, K.W., Song, C.B. and Jeon, Y.J. (2003) Antioxidant Activity of Enzymatic Extracts from Brown Seaweeds. Algae, 18, 71-81.

http://dx.doi.org/10.4490/ALGAE.2003.18.1.071

[66] Ahn, C.B., Jeon, Y.J., Kang, D.S., Shin, T.S. and Jung, B.M. (2004) Free Radical Scavenging Activity of Enzymatic Extracts from a Brown Seaweed Scytosiphon lomentaria by Electron Spin Resonance Spectrometry. Food Research International, 37, 253-258. http://dx.doi.org/10.1016/j.foodres.2003.12.002

[67] Wang, T., Jonsdottir, R., Kristinsson, H.G., Hreggvidsson, G.O., Jonsson, J.O., Thorkelsson, G., et al. (2010) Enzyme-Enhanced Extraction of Antioxidant Ingredients from Red Algae Palmaria palmate. LWT-Food Science and Technology, 43, 1387-1397. http://dx.doi.org/10.1016/j.lwt.2010.05.010

[68] Je, J.Y., Park, P.J., Kim, E.K., Park, J.S., Yoon, H.D., Kim, K.R., et al. (2009) Antioxidant Activity of Enzymatic Extracts from the Brown Seaweed Undaria pinnatifida by Electron Spin Resonance Spectroscopy. LWT-Food Science and Technology, 42, 874-878.

http://dx.doi.org/10.1016/j.lwt.2008.10.012

[69] Chang, C.Y., Wu, K.C. and Chiang, S.H. (2007) Antioxidant Properties and Protein Compositions of Porcine Haemoglobin Hydrolysates. Food Chemistry, 100, 1537-1543. http://dx.doi.org/10.1016/j.foodchem.2005.12.019

[70] Sheih, I.C., Wu, T.K. and Fang, T.J. (2009) Antioxidant Properties of a New Antioxidative Peptide from Algae Protein Hydrolysate in Different Oxidation Systems. Bioresource Technology, 100, 3419-3425. http://dx.doi.org/10.1016/j.biortech.2009.02.014

[71] Samaranayaka, A.G.P. and Li-Chan, E.C.Y. (2011) Food-Derived Peptidic Antioxidants: A Review of Their Production, Assessment, and Potential Applications. Journal of Functional Foods, 3, 229-254. http://dx.doi.org/10.1016/j.jff.2011.05.006

[72] World Cancer Research Fund (2013). www.wcrf.org

[73] Kato, I., Tominaga, S., Matsuura, A., Yoshii, Y., Shirai, M. and Kobayashi, S. (1990) A Comparative Case-Control Study of Colorectal Cancer and Adenoma. Japanese Journal of Cancer Research, 81, 1101-1108. http://dx.doi.org/10.1111/j.1349-7006.1990.tb02520.x

[74] Aceves, C., Anguiano, B. and Delgado, G. (2010) Is Iodine a Gatekeeper of the Integrity of the Mammary Gland? Journal of Mammary Gland Biology and Neoplasia, 10, 189-196. http://dx.doi.org/10.1007/s10911-005-5401-5

[75] Garcia-Solis, P., Alfaro, Y. and Anguiano, B. (2005) Inhibition of $N$-Methyl- $N$-NitrosoureaInduced Mammary Carcinogenesis by Molecular Iodine (I2) but Not by Iodide (I2) Treatment Evidence that I2 Prevents Cancer Promotion. Molecular and Cellular Endocrinology, 236, 49-57. http://dx.doi.org/10.1016/j.mce.2005.03.001

[76] Setchell, K.D., Borriello, S.P., Hulme, P., Kirk, D.N. and Axelson, M. (1984) Nonsteroidal Estrogens of Dietary Origin, Possible Roles in Hormone Dependent Disease. American Journal of Clinical Nutrition, 40, 569-578.

[77] Eskin, B.A., Grotkowski, C.E. and Connolly, C.P. (1995) Different Tissue Responses for Iodine and Iodide in Rat Thyroid and Mammary Glands. Biological Trace Element Research, 49, 9-19. http://dx.doi.org/10.1007/BF02788999

[78] Li, Y., Qian, Z.J., Kim, M.M. and Kim, S.K. (2011) Cytotoxic Activities of Phlorethol and Fucophlorethol Derivatives Isolated from Laminariaceae Ecklonia cava. Journal of Food Biochemistry, 35, 357-369. http://dx.doi.org/10.1111/j.1745-4514.2010.00387.x 
[79] Kong, C.S., Kim, J.A., Yoon, N.Y. and Kim, S.K. (2009) Induction of Apoptosis by Phloroglucinol Derivative from Ecklonia cava in MCF-7 Human Breast Cancer Cells. Food and Chemical Toxicology, 47, 1653-1658. http://dx.doi.org/10.1016/j.fct.2009.04.013

[80] Domijana, A.M., Gajskib, G., Jovanovićc, I.N., Gerićb, M. and Garaj-Vrhovacb, V. (2015) In Vitro Genotoxicity of Mycotoxins Ochratoxin A and Fumonisin B1 Could Be Prevented by Sodium Copper Chlorophyllin-Implication to Their Genotoxic Mechanism. Food Chemistry, 170, 455-462. http://dx.doi.org/10.1016/j.foodchem.2014.08.036

[81] Okai, Y., Hiqashi Okai, K., Yano, Y. and Otani, S. (1996) Identification of Antimutagenic Substances in an Extract of Edible Red Alga, Porphyra tenera (Asadusa-nori). Cancer Letters, 100, 235-240. http://dx.doi.org/10.1016/0304-3835(95)04101-X

[82] Ishikawa, C., Tafuku, S., Kadekaru, T., Sawada, S., Tomita, M., Okudaira, T., et al. (2008) Antiadult T Cell Leukemia Effects of Brown Algae Fucoxanthin and Its Deacetylated Product, Fucoxanthinol. International Journal of Cancer, 123, 2702-2712. http://dx.doi.org/10.1002/ijc.23860

[83] Hosokawa, M., Wanezaki, S., Miyauchi, K., Kurihara, H., Kohno, H., Kawabata, J., et al. (1999) Apoptosis-Inducing Effect of Fucoxanthin on Human Leukemia Cell Line HL-60. Food Science and Technology Research, 5, 243-246. http://dx.doi.org/10.3136/fstr.5.243

[84] Kotake N.E., Terasaki, M. and Nagao, A. (2005) Characterization of Apoptosis Induced by Fucoxanthin in Human Promyelocytic Leukemia Cells. Bioscience, Biotechnology, and Biochemistry, 69, 224-227. http://dx.doi.org/10.1271/bbb.69.224

[85] Hosokawa, M., Kudo, M., Maeda, H., Kohno, H., Tanaka, T. and Miyashita, K. (2004) Fucoxanthin Induces Apoptosis and Enhances the Antiproliferative Effect of the PPAR $\gamma \mathrm{Li}$ gand, Troglitazone, on Colon Cancer Cells. Biochimica et Biophysica Acta (BBA): General Subjects, 1675, 113-119. http://dx.doi.org/10.1016/j.bbagen.2004.08.012

[86] Boominathan, M. and Mahesh, A. Sea Weed Carotenoids for Cancer Therapeutics. Handbook of Anticancer Drugs from Marine Origin. 2015. Ed. Se-Kwon K. Springer. Cap. 10, 193-194.

[87] Kotake N.E., Kushiro, M., Zhang, H., Sugawara, T., Miyashita, K. and Nagao, A. (2001) Carotenoids Affect Proliferation of Human Prostate Cancer Cells. Journal of Nutrition, 131, 3303-3306.

[88] Carmeliet, P. (2003) Angiogenesis in Health and Disease. Nature Medicine, 9, 653-660. http://dx.doi.org/10.1038/nm0603-653

[89] Kirk, S., Frank, J.A. and Karlik, S. (2004) Angiogenesis in Multiple Sclerosis: Is It Good, Bad or an Epiphenomenon? Journal of the Neurological Sciences, 217, 125-130. http://dx.doi.org/10.1016/j.jns.2003.10.016

[90] Koyanagi, S., Tanigawa, N., Nakagawa, H., Soeda, S. and Shimeno, H. (2003) Oversulfation of Fucoidan Enhances Its Antiangiogenic and Antitumor Activities. Biochemical Pharmacology, 65, 173-179. http://dx.doi.org/10.1016/S0006-2952(02)01478-8

[91] Soeda, S., Shibata, Y. and Shimeno, H. (1997) Inhibitory Effect of Oversulfated Fucoidan on Tube Formation by Human Vascular Endothelial Cells. Biological Pharmaceutical Bulletin, 20, 1131-1135. http://dx.doi.org/10.1248/bpb.20.1131

[92] Sugawara, T., Matsubara, K., Akagi, R., Mori, M. and Hirata, T. (2006) Antiangiogenic Activity of Brown Algae Fucoxanthin and Its Deacetylated Product, Fucoxanthinol. Journal of Agricultural and Food Chemistry, 54, 9805-9810. http://dx.doi.org/10.1021/jf062204q

[93] Ganesan, P., Matsubara, K., Ohkubo, T., Tanaka, Y., Noda, K., Sugawara, T., et al. (2010) Anti-Angiogenic Effect of Siphonaxanthin from Green Alga, Codium fragile. Phytomedicine, 17, 1140-1144. http://dx.doi.org/10.1016/j.phymed.2010.05.005 
[94] Rocha, H.A., Franco, C.R., Trindade, E.S., Veiga, S.S., Leite, E.L., Nader, H.B., et al. (2005) Fucan Inhibits Chinese Hamster Ovary Cell (CHO) Adhesion to Fibronectin by Binding to the Extracellular Matrix. Planta Medica, 71, 628-633. http://dx.doi.org/10.1055/s-2005-871268

[95] Kwon, M.J. and Nam, T.J. (2006) Porphyran Induces Apoptosis Related Signal Pathway in AGS Gastric Cancer Cell Lines. Life Sciences, 79, 1956-1962. http://dx.doi.org/10.1016/j.lfs.2006.06.031

[96] Teruya, T., Konishi, T., Uechi, S., Tamaki, H. and Tako, M. (2007) Anti-Proliferative Activity of Oversulfated Fucoidan from Commercially Cultured Cladosiphon okamuranus Tokida in U937 Cells. International Journal of Biological Macromolecules, 41, 221-226. http://dx.doi.org/10.1016/j.ijbiomac.2007.02.010

[97] Haneji, K., Matsuda, T., Tomita, M., Kawakami, H., Ohshiro, K., Uchihara, J.N., Masuda, M., Takasu, N., Tanaka, Y., Ohta, T. and Mori, N. (2005) Fucoidan Extracted from Cladosiphon okamuranus Tokida Induces Apoptosis of Human T-Cell Leukemia Virus Type 1-Infected T-Cell Lines and Primary Adult T-Cell Leukemia Cells. Nutrition and Cancer, 52, 189-201. http://dx.doi.org/10.1207/s15327914nc5202 9

[98] Alekseyenko, T.V., Zhanayeva, S.Y., Venediktova, A.A., Zvyagintseva, T.N., Kuznetsova, T.A., Besednova, N.N. and Korolenko, T.A. (2007) Antitumor and Antimetastatic Activity of Fucoidan, a Sulfated Polysaccharide Isolated from the Okhotsk Sea Fucus evanescens Brown Alga. Bulletin of Experimental Biology and Medicine, 143, 730-732. http://dx.doi.org/10.1007/s10517-007-0226-4

[99] Coombe, D.R., Parish, C.R., Ramshaw, I.A. and Snowden, J.M. (1987) Analysis of the Inhibition of Tumour Metastasis by Sulphated Polysaccharides. International Journal of Cancer, 39, 82-88. http://dx.doi.org/10.1002/ijc.2910390115

[100] Song, J.Q., Xu, Y.T. and Zhang, H.K. (2000) Immunomodulation Action of Sulfate Polysaccharide of Laminaria japonica on Peritoneal Macrophages of Mice. Chinese Journal of Microbiology and Immunology, 16, 70.

[101] Maruyama, H., Tamauchib, H., Iizuka, M. and Nakano, T. (2006) The Role of NK Cells in Antitumor Activity of Dietary Fucoidan from Undaria pinnatifida Sporophylls (Mekabu). Planta Medica, 72, 1415-1417. http://dx.doi.org/10.1055/s-2006-951703

[102] Choi, E.M., Kim, A.J., Kim, Y. and Hwang, J.K. (2005) Immunomodulating Activity of Arabinogalactan and Fucoidan in Vitro. Journal of Medicinal Food, 8, 446-453.

http://dx.doi.org/10.1089/jmf.2005.8.446

[103] Wardwell, L., Chapman-Novakofski, H.S. and Woods, J. (2008) Nutrient Intake and Immune Function of Elderly Subjects. Journal of the American Dietetic Association, 108, 2005-2012.

[104] Martin, C.A. (2000) EU-Funded Project on the Elderly. Nutrition and Food Science, 30, 279-282. http://dx.doi.org/10.1108/00346650010352807

[105] Volkert, D. (2005) Nutrition and Lifestyle of the Elderly in Europe. Journal of Public Health, 13, 56-61. http://dx.doi.org/10.1007/s10389-004-0092-8

[106] Makinodan, T., James, S.J., Inamizu, T. and Chang, M.P. (1984) Immunologic Basis for Susceptibility to Infection in the Aged. Gerontology, 30, 279-289. http://dx.doi.org/10.1159/000212647

[107] Vo, T.S., Ngo, D.H. and Kim, S.K. (2012) Potential Targets for Anti-Inflammatory and Anti-Allergic Activities of Marine Algae: An Overview. Inflammation and Allergy-Drug Targets, 11, 90-101. http://dx.doi.org/10.2174/187152812800392797

[108] Block, M., Zecca, L. and Hong, J. (2007) Microglia-Mediated Neurotoxicity: Uncovering the 
Molecular Mechanisms. Nature Reviews Neuroscience, 8, 57-69.

http://dx.doi.org/10.1038/nrn2038

[109] Okai, Y. and Hiqashi, O.K. (1997) Potent Anti-Inflammatory Activity of Pheophytin a Derived from Edible Green Alga, Enteromorpha prolifera (Sujiao-nori). International Journal of Immunopharmacology, 19, 355-358. http://dx.doi.org/10.1016/S0192-0561(97)00070-2

[110] Shiratori, K., Ohgami, K., Ilieva, I., Jin, X.H., Koyama, Y., Miyashita, K., et al. (2005) Effects of Fucoxanthin on Lipopolysaccharide-Induced Inflammation in Vitro and in Vivo. Experimental Eye Research, 81, 422-428. http://dx.doi.org/10.1016/j.exer.2005.03.002

[111] Heo, S.J., Yoon, W.J., Kim, K.N., Ahn, G.N., Kang, S.M., Kang, D.H., et al. (2010) Evaluation of Anti-Inflammatory Effect of Fucoxanthin Isolated from Brown Algae in Lipopolysaccharide Stimulated RAW 264.7 Macrophages. Food and Chemical Toxicology, 48, 20452051. http://dx.doi.org/10.1016/j.fct.2010.05.003

[112] Kim, K.N., Heo, S.J., Yoon, W.J., Kang, S.M., Ahn, G., Yi, T.H., et al. (2010) Fucoxanthin Inhibits the Inflammatory Response by Suppressing the Activation of NF-kB and MAPKs in Lipopolysaccharide-Induced RAW 264.7 Macrophages. European Journal of Pharmacology, 649, 369-375. http://dx.doi.org/10.1016/j.ejphar.2010.09.032

[113] Senni, K., Gueniche, F., Bertaud, A.F., Tchen, S.I., Fioretti, F., Jouault, S.C., Durand, P., Guezennec, J., Godeau, G. and Letourneur, D. (2006) Fucoidan a Sulfated Polysaccharide from Brown Algae Is a Potent Modulator of Connective tissue Proteolysis. Archives of Biochemistry and Biophysics, 445, 56-64. http://dx.doi.org/10.1016/j.abb.2005.11.001

[114] Cui, Y.Q., Zhang, L.J., Zhang, T., Luo, D.Z., Jia, Y.J., Guo, Z.X., Zhang, Q.B., Wang, X. and Wang, X.M. (2010) Inhibitory Effect of Fucoidan on Nitric Oxide Production in Lipopolysaccharide Activated Primary Microglia. Clinical and Experimental Pharmacology and Physiology, 37, 422-428. http://dx.doi.org/10.1111/j.1440-1681.2009.05314.x

[115] Park, H.Y., Han, M.H., Park, C., Jin, C.Y., Kim, G.Y., Choi, I.W., Kim, N.D., Nam, T.J., Kwon, T.K. and Choi, Y.H. (2011) Antiinflammatory Effects of Fucoidan through Inhibition of NF-B, MAPK and Akt Activation in Lipopolysaccharide-Induced BV2 Microglia Cells. Food and Chemical Toxicology, 49, 1745-1752. http://dx.doi.org/10.1016/j.fct.2011.04.020

[116]Jung, W., Heo, S., Jeon, Y., Lee, C., Park, Y., Byun, H., Choi, Y., Park, S. and Choi, I. (2009) Inhibitory Effects and Molecular Mechanism of Dieckol Isolated from Marine Brown alga on COX-2 and iNOS in Microglial Cells. Journal of Agricultural and Food Chemistry, 57, 4439-4446. http://dx.doi.org/10.1021/jf9003913

[117] Jung, W.K., Ahn, Y.W., Lee, S.H., Choi, Y.H., Kim, S.K., Yea, S.S., Choi, I., Park, S.G., Seo, S.K., Lee, S.W. and Choi, I.W. (2009) Ecklonia cava Ethanolic Extracts Inhibit Lipopolysaccharide-Induced Cyclooxygenase-2 and Inducible Nitric Oxide Synthase Expression in BV2 Microglia via the MAP Kinase and NF- $\kappa$ B Pathways. Food and Chemical Toxicology, 47, 410-417. http://dx.doi.org/10.1016/j.fct.2008.11.041

[118] Ley, K. (2003) The Role of Selectins in Inflammation and Disease. Trends in Molecular Medicine, 9, 263-268. http://dx.doi.org/10.1016/S1471-4914(03)00071-6

[119] Bachelet, L., Bertholon, I., Lavigne, D., Vassy, R., Jandrot-Perrus, M., Chaubet, F. and Letourneur, D. (2009) Affinity of Low Molecular Weight Fucoidan for P-Selectin Triggers Its Binding to Activated Human Platelets. Biochimica et Biophysica Acta, 1790, 141-146. http://dx.doi.org/10.1016/j.bbagen.2008.10.008

[120] Chauvet, P., Bienvenu, J.G., Théorê, T.J.F., Latour, J.G. and Merhi, Y. (1999) Inhibition of Platelet-Neutrophil Interactions by Fucoidan Reduces Adhesion and Vasoconstriction after Acute Arterial Injury by Angioplasty in Pigs. Journal of Cardiovascular Pharmacology, 34, 597-603. http://dx.doi.org/10.1097/00005344-199910000-00018 
[121] Preobrazhenskaya, M.E., Berman, A.E., Mikhailov, V.I., Ushakova, N.A., Mazurov, A.V., Semenov, A.V., Usov, A.I., Nifantév, N.E. and Bovin, N.V. (1997) Fucoidan Inhibits Leukocyte Recruitment in a Model Peritoneal Inflammation in Rat and Blocks Interaction of P-Selectin with Its Carbohydrate Ligand. Biochemistry and Molecular Biology International, 43, 443-451.

[122] Semenov, A.V., Mazurov, A.V., Preobrazhenskaia, M.E., Ushakova, N.A., Mikhalov, V.I., Berman, A.E., Usov, A.I., Nifantév, N.E. and Bovin, N.V. (1998) Sulfated Polysaccharides as Inhibitors of Receptor Activity of P-Selectin and P-Selectin Dependent Inflammation. Voprosy Meditsinskoi Khimii, 44, 135-144.

[123] Ogata, M., Matsui, T., Kita, T. and Shigematsu, A. (1999) Carrageenan Primes Leukocytes to Enhance Lipopolysaccharide-Induced Tumor Necrosis Factor Alpha Production. Infection and Immunity, 67, 3284-3289.

[124] Nacife, V.P., Soeiro, M.D.N.C., Araujo-Jorge, T.C., Neto, H.C.C. and Meirelles, M.D.N.L. (2000) Ultrastructural, Immunocytochemical and Flow Cytometry Study of Mouse Peritoneal Cells Stimulated with Carrageenan. Cell Structure and Function, 25, 337-350. http://dx.doi.org/10.1247/csf.25.337

[125] Van, R.N. and Sanders, A. (1997) Elimination, Blocking, and Activation of Macrophages: Three of a Kind? Journal of Leukocyte Biology, 62, 702-709.

[126] Yang, J.W., Yoon, S.Y., Oh, S.J., Kim, S.K. and Kang, K.W. (2006) Bifunctional Effects of Fucoidan on the Expression of Inducible Nitric Oxide Synthase. Biochemical and Biophysical Research Communications, 346, 345-350. http://dx.doi.org/10.1016/j.bbrc.2006.05.135

[127] Yoshizawa, Y., Enomoto, A., Todoh, H., Ametani, A. and Kaminogawa, S. (1993) Activation of Murine Macrophages by Polysaccharide Fractions from Marine Algae (Porphyra yezoensis). Bioscience, Biotechnology and Biochemistry, 57, 1862-1866.

http://dx.doi.org/10.1271/bbb.57.1862

[128] Yoshizawa, Y., Tsunehiro, J., Nomura, K., Itoh, M., Fukui, F., Ametani, A., et al. (1996) In Vivo Macrophage-Stimulation Activity of the Enzyme-Degraded Water-Soluble Polysaccharide Fraction from a Marine Alga (Gracilaria verrucosa). Bioscience, Biotechnology and Biochemistry, 60, 1667-1671. http://dx.doi.org/10.1271/bbb.60.1667

[129] Leiro, J.M., Castro, R., Arranz, J.A. and Lamas, J. (2007) Immunomodulating Activities of Acidic Sulphated Polysaccharides Obtained from the Seaweed Ulva rigida C. Agardh. International Immunopharmacology, 7, 879-888. http://dx.doi.org/10.1016/j.intimp.2007.02.007

[130] Samarakoon, K. and Jeon, Y.J. (2012) Bio-Functionalities of Proteins Derived from Marine Algae-A Review. Food Research International, 48, 948-960.

http://dx.doi.org/10.1016/j.foodres.2012.03.013

[131] Kim, S.K. and Wijesekara, I. (2010) Development and Biological Activities of Marine-Derived Bioactive Peptides: A Review. Journal of Functional Foods, 2, 1-9. http://dx.doi.org/10.1016/j.jff.2010.01.003

[132] Becker, E.W. (2007) Micro Algae as a Source of Protein. Biotechnology Advances, 25, $207-$ 210. http://dx.doi.org/10.1016/j.biotechadv.2006.11.002

[133] Morris, H.J., Carrillo, O., Almarales, A., Bermúdez, R.C., Lebeque, Y., Fontaine, R., et al. (2007) Immunostimulant Activity of an Enzymatic Protein Hydrolysate from Green Microalga Chlorella vulgaris on Undernourished Mice. Enzyme and Microbial Technology, 40, 456-460. http://dx.doi.org/10.1016/j.enzmictec.2006.07.021

[134] Ahn, G., Hwang, I., Park, E.J., Kim, J.H., Jeon, Y.J., Lee, J.H., et al. (2008) Immunomodulatory Effects of an Enzymatic Extracts from Ecklonia cava on Murine Splenocytes. Marine 
Biotechnology, 10, 278-289. http://dx.doi.org/10.1007/s10126-007-9062-9

[135] Kong, C.S., Kim, J.A. and Kim, S.K. (2009) Anti-Obesity Effect of Sulfated Glucosamine by AMPK Signal Pathway in 3T3-L1 Adipocytes. Food and Chemical Toxicology, 47, 24012406. http://dx.doi.org/10.1016/j.fct.2009.06.010

[136] Kopelman, P.G. (2000) Obesity as a Medical Problem. Nature, 404, 635-643.

[137] Spiegelman, B.M. and Flier, J.S. (2001) Obesity and the Regulation of Energy Balance. Cell, 104, 531-543. http://dx.doi.org/10.1016/S0092-8674(01)00240-9

[138] Kelishadi, R. (2007) Childhood Overweight, Obesity, and the Metabolic Syndrome in Developing Countries. Epidemiologic Reviews, 29, 62-76. http://dx.doi.org/10.1093/epirev/mxm003

[139] Volkert, D. (2002) Malnutrition in the Elderly-Prevalence, Causes and Corrective Strategies. Clinical Nutrition, 110-111. http://dx.doi.org/10.1016/S0261-5614(02)80014-0

[140] Caroline, W.T. (2004) Eating Well for Older People. The Caroline Walker Trust, London.

[141] Hayato, M., Masashi, H., Tokutake, S., Nobuyuki, T., Teruo, K. and Kazuo, M. (2006) Fucoxanthin and Its Metabolite, Fucoxanthinol, Suppress Adipocyte Differentiation in 3T3-L1 Cells. International Journal of Molecular Medicine, 18, 147-152.

[142] Okada, T., Nakai, M., Maeda, H., Hosokawa, M., Sashima, T. and Miyashita, K. (2008) Suppressive Effect of Neoxanthin on the Differentiation of 3T3-L1 Adipose Cells. Journal of Oleo Science, 57, 345-351. http://dx.doi.org/10.5650/jos.57.345

[143] Trayhurn, P. and Wood, I.S. (2005) Signalling Role of Adipose Tissue: Adipokines and Inflammation in Obesity. Biochemical Society Transactions, 33, 1078-1081. http://dx.doi.org/10.1042/BST0331078

[144] Park, M.K., Jung, U. and Roh, C. (2011) Fucoidan from Marine Brown Algae Inhibits Lipid Accumulation. Marine Drugs, 9, 1359-1367. http://dx.doi.org/10.3390/md9081359

[145] Paxman, J.R., Richardson, J.C., Dettmar, P.W. and Corfe, B.M. (2008) Daily Ingestion of Alginate Reduces Energy Intake in Free Living Subjects. Appetite, 51, 713-719. http://dx.doi.org/10.1016/j.appet.2008.06.013

[146] Darmon, P., Kaiser, M.J., Bauer, J.M., Sieber, C.C. and Pichard, C. (2010) Restrictive Diets in the Elderly: Never Say Never Again? Clinical Nutrition, 29, 170-174.

[147] Howarth, C., Kouris-Blazos, A., Savige, G.S. and Wahlqvist, M.L. (1999) Eating Your Way to a Successful Old Age, with Special Reference to Older Women. Asia Pacific Journal of Clinical Nutrition, 8, 216-255. http://dx.doi.org/10.1046/j.1440-6047.1999.00116.x

[148] Ritz, P. (2001) Factors Affecting Energy and Macronutrient Requirements in Elderly People. Public Health Nutrition, 4, 561-568. http://dx.doi.org/10.1079/PHN2001141

[149] Park, J.S. and Ahn, C.W. (2007) Educational Program for Diabetic Patients in Korea-Multidisplinary Intensive Management. Diabetes Research and Clinical Practice, 77, 194-198. http://dx.doi.org/10.1016/j.diabres.2007.01.056

[150] Woo, Y.J., Lee, H.S. and Kim, W.Y. (2006) Individual Diabetes Nutrition Education Can Help Management for Type II Diabetes. The Korean Journal of Nutrition, 36, 641-648.

[151] Lee, E.L., Park, J.E., Choi, Y.J., Huh, K.B. and Kim, W.Y. (2008) A Randomized Study to Establish the Effects of Spirulina in Type 2 Diabetes Mellitus Patients. Nutrition Research and Practice, 2, 295-300. http://dx.doi.org/10.4162/nrp.2008.2.4.295

[152] Hosokawa, M., Miyashita, T., Emi, S., Tsukui, T., Beppu, F., Okada, T. and Miyashita, K. (2010) Fucoxanthin Regulates Adipocytokine mRNA Expression in White Adipose Tissue of Diabetic/Obese KK- $A^{y}$ Mice. Archives of Biochemistry and Biophysics, 504, 17-25. http://dx.doi.org/10.1016/j.abb.2010.05.031 
[153] Maeda, H., Hosokawa, M., Sashima, T. and Miyashita, K. (2007) Dietary Combination of Fucoxanthin and Fish Oil Attenuates the Weight Gain of White Adipose Tissue and Decreases Blood Glucose in Obese/Diabetic KK- $A^{y}$ Mice. Journal of Agricultural and Food Chemistry, 55, 7701-7706. http://dx.doi.org/10.1021/jf071569n

[154] Maeda, H., Hosokawa, M., Sashima, T., Murakami-Funayama, K. and Miyashita, K. (2009) Anti-Obesity and Anti-Diabetic Effects of Fucoxanthin on Diet-Induced Obesity Conditions in a Murine Model. Molecular Medicine Reports, 2, 897-902.

http://dx.doi.org/10.3892/mmr 00000189

[155] Cariello, A. (2005) Postprandial Hyperglycemia and Diabetes Complications: It Is Time to Treat? Diabetes, 54, 1-7. http://dx.doi.org/10.2337/diabetes.54.1.1

[156] Baron, A.D. (1998) Postprandial Hyperglycemia and $\alpha$-Glucosidase Inhibitors. Diabetes Research and Clinical Practice, 40, S51-S55. http://dx.doi.org/10.1016/S0168-8227(98)00043-6

[157] Uebanso, T., Arai, H., Taketani, Y., Fukaya, M. and Yamamoto, H. (2007) Extracts of Momordica charantia Suppress Postprandial Hyperglycemia in Rats. Journal of Nutritional Science and Vitaminology, 53, 482-488. http://dx.doi.org/10.3177/jnsv.53.482

[158] Coniff, R. and Krol, A. (1997) Acarbose: A Review of US Clinical Experience. Clinical Therapeutics, 19, 16-26. http://dx.doi.org/10.1016/S0149-2918(97)80069-0

[159] Ohta, T., Sasaki, S., Oohori, T., Yoshikawa, S. and Kurihara, H. (2002) $\alpha$-Glucosidase Inhibitory Activity of a 70\% Methanol Extract from Ezoishige (Pelvetia babingtonii de Toni) and Its Effect on the Elevation of Blood Glucose Level in Rats. Bioscience, Biotechnology, and Biochemistry, 66, 1552-1554. http://dx.doi.org/10.1271/bbb.66.1552

[160] Zhang, J., Christa, T., Jingkai, S., Can, W., Gabrielle, S.G., Dorothy, D., et al. (2007) Antidiabetic Properties of Polysaccharide- and Polyphenolic-Enriched Fractions from the Brown Seaweed Ascophyllum nodosum. Canadian Journal of Physiology and Pharmacology, 85, 1116-1123. http://dx.doi.org/10.1139/Y07-105

[161] Kim, K.Y., Nama, K.A., Kurihara, H. and Kim, S.M. (2008) Potent $\alpha$-Glucosidase Inhibitors Purified from the Red Alga Grateloupia elliptica. Phytochemistry, 69, 2820-2825. http://dx.doi.org/10.1016/j.phytochem.2008.09.007

[162] Lee, S.H., Li, Y., Karadeniz, F., Kim, M.M. and Kim, S.K. (2009) $\alpha$-Glucosidase and $\alpha$-Amylase Inhibitory Activities of Phloroglucinal Derivatives from Edible Marine Brown Alga, Ecklonia cava. Journal of the Science of Food and Agriculture, 89, 1552-1558. http://dx.doi.org/10.1002/jsfa.3623

[163] Bjarkam, C.R., Sørensen, J.C., Sunde, N.Å., Geneser, F.A. and Østergaard, K. (2001) New Strategies for the Treatment of Parkinson's Disease Hold Considerable Promise for the Future Management of Neurodegenerative Disorders. Biogerontology, 2, 193-207. http://dx.doi.org/10.1023/A:1011565207964

[164] Ansari, J., Siraj, A. and Inamdar, N. (2010) Pharmacotherapeutic Approaches of Parkinson's Disease. International Journal of Pharmacology, 6, 584-590. http://dx.doi.org/10.3923/ijp.2010.584.590

[165] Akyol, Ö., Herken, H., Uz, E., FadIllIolu, E., Ünal, S., Söüt, S., Özyurt, H. and Sava, H. (2002) The Indices of Endogenous Oxidative and Antioxidative Processes in Plasma from Schizophrenic Patients. 1: The Possible Role of Oxidant/Antioxidant Imbalance. Progress in Neuro-Psychopharmacology \& Biological Psychiatry, 26, 995-1005.

[166] Migliore, L. and Coppedè, F. (2009) Environmental-Induced Oxidative Stress in Neurodegenerative Disorders and Aging. Mutation Research/Genetic Toxicology and Environmental Mutagenesis, 674, 73-84. http://dx.doi.org/10.1016/j.mrgentox.2008.09.013 
[167] Behl, C. and Moosmann, B. (2002) Antioxidant Neuroprotection in Alzheimer's Disease as Preventive and Therapeutic Approach. Free Radical Biology and Medicine, 33, 182-191. http://dx.doi.org/10.1016/S0891-5849(02)00883-3

[168] Lim, C., Jin, D., Sung, J., Lee, J., Choi, H., Ha, I. and Han, J. (2006) Antioxidant and AntiInflammatory Activities of the Methanolic Extract of Neorhodomela aculeate in Hippocampal and Microglial Cells. Biological and Pharmaceutical Bulletin, 29, 1212-1216. http://dx.doi.org/10.1248/bpb.29.1212

[169] Fallarero, A., Loikkanen, J.J., Männistö, P.T., Castañeda, O. and Vidal, A. (2003) Effects of Aqueous Extracts of Halimeda incrassata (Ellis) Lamouroux and Bryothamnion triquetrum (S.G.Gmelim) Howe on Hydrogen Peroxide and Methyl Mercury-Induced Oxidative Stress in GT1-7 Mouse Hypothalamic Immortalized Cells. Phytomedicine, 10, 39-47. http://dx.doi.org/10.1078/094471103321648647

[170] Khodosevich, K. and Monyer, H. (2010) Signaling Involved in Neurite Outgrowth of Postnatally Born Subventricular Zone Neurons in Vitro. BMC Neuroscience, 11, 18. http://dx.doi.org/10.1186/1471-2202-11-18

[171] Okuzumi, J., Nishino, H., Murakoshi, M., Iwashima, A., Tanaka, Y., Yamane, T., et al. (1990) Inhibitory Effects of Fucoxanthin, a Natural Carotenoid, on N-myc Expression and Cell Cycle Progression in Human Malignant Tumor Cells. Cancer Letters, 55, 75-81. http://dx.doi.org/10.1016/0304-3835(90)90068-9

[172] Cui, Y., Park, J.-U., Wu, J., Lee, J.H., Yang, Y.-S., Kang, M.-S., Jung, S.-C., Park, J.M., Yoo, E-S., Seong-Ho Kim, S.-H., Jo, S.A., Suk, K. and Eun, S. (2015) Dieckol Attenuates Microglia-Mediated Neuronal Cell Death via ERK, Akt and NADPH Oxidase-Mediated Pathways. Korean Journal of Physiology and Pharmacology, 3, 219-228.

[173] Allen, N. and Barres, B. (2009) Neuroscience: Glia-More than Just Brain Glue. Nature, 457, 675-677. http://dx.doi.org/10.1038/457675a

[174] Graeber, M.B. (2010) Changing Face of Microglia. Science, 330, 783-788. http://dx.doi.org/10.1126/science.1190929

[175] Liu, B.I.N., Gao, H.M., Wang, J.Y., Jeohn, G.H., Cooper, C.L. and Hong, J.S. (2002) Role of Nitric Oxide in Inflammation-Mediated Neurodegeneration. Annals of the New York Academy of Sciences, 962, 318-331. http://dx.doi.org/10.1111/j.1749-6632.2002.tb04077.x

[176] Lull, M.E. and Block, M.L. (2010) Microglial Activation and Chronic Neurodegeneration. Neurotherapeutics, 7, 354-365. http://dx.doi.org/10.1016/j.nurt.2010.05.014

[177] Vane, J. and Botting, R. (1995) New Insights into the Mode of Action of Anti-Inflammatory Drugs. Inflammation Research, 44, 1-10. http://dx.doi.org/10.1007/BF01630479

[178] Boscá, L., Zeini, M., Través, P. and Hortelano, S. (2005) Nitric Oxide and Cell Viability in Inflammatory Cells: A Role for NO in Macrophage Function and Fate. Toxicology, 208, 249-258. http://dx.doi.org/10.1016/j.tox.2004.11.035

[179] Heales, S., Bolaños, J., Stewart, V., Brookes, P., Land, J. and Clark, J. (1999) Nitric Oxide, Mitochondria and Neurological Disease. Biochimica et Biophysica Acta (BBA)-Bioenergetics, 1410, 215-228. http://dx.doi.org/10.1016/S0005-2728(98)00168-6

[180] Lee, J., Grabb, M., Zipfel, G. and Choi, D. (2000) Brain Tissue Responses to Ischemia. The Journal of Clinical Investigation, 106, 723-731. http://dx.doi.org/10.1172/JCI11003

[181] Sarwar, B., Suryakanta, S., Hameed, H., Abul, B.M. and Sarfaraz, H.M. (2011) Systematic Review of Herbals as Potential Anti-Inflammatory Agents: Recent Advances, Current Clinical Status and Future Perspectives. (Review Article). Pharmacognosy Reviews, 5, 120-137. http://dx.doi.org/10.4103/0973-7847.91102

[182] Jin, D., Lim, C., Sung, J., Choi, H., Ha, I. and Han, J. (2006) Ulva conglobata, a Marine Al- 
gae, Has Neuroprotective and Anti-Inflammatory Effects in Murine Hippocampal and Microglial Cells. Neuroscience Letters, 402, 154-158.

http://dx.doi.org/10.1016/j.neulet.2006.03.068

[183] Salvemini, D., Manning, P., Zweifel, B., Seibert, K., Connor, J., Currie, M., Needleman, P. and Masferrer, J. (1995) Dual Inhibition of Nitric Oxide and Prostaglandin Production Contributes to the Antinflammatory Properties of Nitric Oxide Synthase Inhibitors. The Journal of Clinical Investigation, 96, 301-308. http://dx.doi.org/10.1172/JCI118035

[184] Tabet, N. (2006) Acetylcholinesterase Inhibitors for Alzheimer's Disease: Anti-Inflammatories in Acetylcholine Clothing! Age and Ageing, 35, 336-338. http://dx.doi.org/10.1093/ageing/afl027

[185] Pangestuti, R. and Kim, S.K. (2010) Neuroprotective Properties of Chitosan and Its Derivatives. Marine Drugs, 8, 2117-2128. http://dx.doi.org/10.3390/md8072117

[186] Yoon, N.Y., Lee, S.H., Yong, L. and Kim, S.K. (2009) Phlorotannins from Ishige okamurae and Their Acetyl- and Butyrylcholinesterase Inhibitory Effects. Journal of Functional Foods, 1, 331-335. http://dx.doi.org/10.1016/j.jff.2009.07.002

[187] Suganthy, N., Karutha Pandian, S. and Pandima Devi, K. (2010) Neuroprotective Effect of Seaweeds Inhabiting South Indian Coastal Area (Hare Island, Gulf of Mannar Marine Biosphere Reserve): Cholinesterase Inhibitory Effect of Hypnea valentiae and Ulva reticulata. Neuroscience Letters, 468, 216-219. http://dx.doi.org/10.1016/j.neulet.2009.11.001

[188] Jhamandas, J.H., Wie, M.B., Harris, K., MacTavish, D. and Kar, S. (2005) Fucoidan Inhibits Cellular and Neurotoxic Effects of $\beta$-Amyloid $(\mathrm{A} \beta)$ in Rat Cholinergic Basal Forebrain Neurons. European Journal of Neuroscience, 21, 2649-2659.

http://dx.doi.org/10.1111/j.1460-9568.2005.04111.x

[189] Cowan, C.M., Thai, J., Krajewski, S., Reed, J.C., Nicholson, D.W., Kaufmann, S.H. and Roskams, A.J. (2001) Caspases 3 and 9 Send a Pro-Apoptotic Signal from Synapse to Cell Body in Olfactory Receptor Neurons. The Journal of Neuroscience, 21, 7099-7109.

[190] Wong, K.H.P. and Cheung, C.K. (2000) Nutritional Evaluation of Some Subtropical Red and Green Seaweeds Part I: Proximate Composition, Amino Acid Profiles and Some Physico-Chemical Properties. Food Chemistry, 71, 475-482. http://dx.doi.org/10.1016/S0308-8146(00)00175-8

[191] Matanjun, P., Mohamed, S., Mustapha, N.M. and Muhammad, K. (2009) Nutrient Content of Tropical Edible Seaweeds, Eucheuma cottonii, Caulerpa lentillifera and Sargassum polycystum. Journal of Applied Phycology, 21, 75-80.

http://dx.doi.org/10.1007/s10811-008-9326-4

[192] Slavin J. (2013) Fiber and Prebiotics: Mechanisms and Health Benefits (Review). Nutrients, 5, 1417-1435 http://dx.doi.org/10.3390/nu5041417.

[193] Yu, P., Ning, L., Xiguang, L., Gefei, Z., Quanbin, Z. and Pengchen, L. (2003) Antihyperlipidemic Effects of Different Molecular Weight Sulfated Polysaccharides from Ulva pertusa (Chlorophyta). Pharmacological Research, 48, 543-549.

http://dx.doi.org/10.1016/S1043-6618(03)00215-9

[194] Inoue, N., Yamano, N., Sakata, K., Nagao, K., Hama, Y. and Yanagita, T. (2009) The Sulfated Polysaccharide Porphyran Reduces Apolipoprotein B100 Secretion and Lipid Synthesis in HepG2 Cells. Bioscience, Biotechnology and Biochemistry, 73, 447-449. http://dx.doi.org/10.1271/bbb.80688

[195] Huff, M.W. and Burnett, J.R. (1997) 3-Hydroxy-3-methylglutaryl Coenzyme A Reductase Inhibitors and Hepatic Apolipoprotein B Secretion. Current Opinion in Lipidology, 8, 138145. http://dx.doi.org/10.1097/00041433-199706000-00003 
[196] Nagaoka, M., Shibata, H., Kimura-Takagi, I., Hashimoto, S., Aiyama, R., Ueyama, S., et al. (2000) Anti-Ulcer Effects and Biological Activities of Polysaccharides from Marine Algae. BioFactors, 12, 267-274. http://dx.doi.org/10.1002/biof.5520120140

[197] Shibata, H., Kimura-Takagi, I., Nagaoka, M., Hashimoto, S., Aiyama, R., Iha, M., et al. (2000) Properties of Fucoidan from Cladosiphon okamuranus Tokida in Gastric Mucosal Protection. BioFactors, 11, 235-245. http://dx.doi.org/10.1002/biof.5520110402

Submit or recommend next manuscript to SCIRP and we will provide best service for you:

Accepting pre-submission inquiries through Email, Facebook, LinkedIn, Twitter, etc. A wide selection of journals (inclusive of 9 subjects, more than 200 journals)

Providing 24-hour high-quality service

User-friendly online submission system

Fair and swift peer-review system

Efficient typesetting and proofreading procedure

Display of the result of downloads and visits, as well as the number of cited articles Maximum dissemination of your research work

Submit your manuscript at: http://papersubmission.scirp.org/

Or contact fns@scirp.org 